\title{
Climate change impact on crop rotations of winter durum wheat and tomato in Southern Italy: yield analysis and soil fertility
}

\author{
Domenico Ventrella, Luisa Giglio, Monia Charfeddine, Raffaele Lopez, Mirko Castellini, \\ Donato Sollitto, Annamaria Castrignanò, Francesco Fornaro \\ Consiglio per la Ricerca e la sperimentazione in Agricoltura - Unità di ricerca per i Sistemi \\ Colturali degli Ambienti caldo-aridi (CRA-SCA), Bari, Italy
}

\begin{abstract}
Cropping systems are affected by climate change because of the strong relationship between crop development, growth, yield, $\mathrm{CO}_{2}$ atmospheric concentration and climate conditions. The increasing temperatures and the reduction of available water resources may result in negative impacts on the agricultural activity in Mediterranean environments than other areas. In this study the CERES-Wheat and CROPGRO-Tomato models were used to assess the effects of climate change on winter wheat (Triticum durum L.) and processing tomato (Lycopersicon aesculentum Mill.) in one of most productive areas of Italy, located in the northern part of the Puglia region. In particular we have compared three different General Circulation Models (HadCM3, CCSM3, ECHAM5) subjected to a statistical downscaling under two future IPCC scenarios (B1 and A2). The analysis was carried out at regional scale repeating the simulations for seven homogeneous area characterizing the spatial variability of the region. In the second part of the study, considering only HadCM3 data set, climate change impact on long-term sequences of the two crops combined in three crop rotations, were evaluated in terms of yield performances and soil fertility as indicated by the soil organic content of carbon and nitrogen. The comparison between GCMs showed no significant differences for winter durum wheat yield, while noticeable dif-
\end{abstract}

Correspondence: Domenico Ventrella, Consiglio per la Ricerca e la sperimentazione in Agricoltura, Unità di ricerca per i Sistemi colturali degli Ambienti caldo-aridi (CRA-SCA), via Celso Ulpiani 5, 70125 Bari, Italy.

E-mail: domenico.ventrella@entecra.it

Key words: DSSAT model, CENTURY-module, climate change, winter durum wheat, tomato, crop rotation.

Acknowledgements: this research was funded by CLIMESCO Evolution of cropping systems as affected by climate change project, contract n. 285, 20/02/2006 (Ministry for Education, University and Research).

Received for publication: 19 April 2011.

Accepted for publication: 16 December 2011.

CC Copyright D. Ventrella et al., 2012

Licensee PAGEPress, Italy

Italian Journal of Agronomy 2012; 7:e15

doi:10.4081/ija.2012.e15

This article is distributed under the terms of the Creative Commons Attribution Noncommercial License (by-nc 3.0) which permits any noncommercial use, distribution, and reproduction in any medium, provided the original author(s) and source are credited. ferences were found for yield and irrigation requirements of tomato. Under future scenarios, the production levels were reduced for tomato, whereas positive yield effects were observed for winter durum wheat. For winter durum wheat the simulation indicated that two- and three-year rotations, including one year of tomato cultivation, improved the cereal yield and this positive effect maintained its validity also in future scenarios. For both crops higher requirements of water and nitrogen were predicted under future scenarios. This result coupled with the decrease of yield caused negative reduction of water use efficiency and nitrogen use efficiency for tomato cultivation.

\section{Introduction}

Climatic variability plays an important role on agricultural productions with a significant impact on crop growth, development and yield, making the agriculture activity one of the most sensitive and vulnerable sectors among the anthropic activities.

The Fourth Assessment Report (AR4) IPCC's relates that continued greenhouse gases (GHG) emission might induce many changes in the global climate system during the $21^{\text {th }}$ century that would be very likely larger than these observed during the $20^{\text {th }}$ century (IPCC, 2007a).

Using of climate change scenarios, diffusively generated by GCM (General Circulation Model) simulations, was essential to climate change assessments on agricultural and water resources for the past 20 years. In fact, various future scenarios have been defined and reported in the SRES (Special Report Emission Scenarios) in order to describe the forecasted GHG emissions and the corresponding socioeconomic development (IPCC, 2000). To evaluate climatic change impacts on agriculture it is necessary to use climate data at regional and daily scale. Several methods of downscaling based on GCM simulations are developed to accommodate these scale differences obtaining climate data on a finer scale that capture the effects of local and regional features in areas with complex surface physiography (Pizzigalli et al., 2012).

Because of the complexity of the soil-plant systems, some crop simulation models take into account several factors of crop-environment interactions and can predict quantitatively and qualitatively crop yields. DSSAT (Decision Support System for Agrotechnology Transfer; Jones et al., 2003) is an excellent example of decision support system that allows users to combine technical knowledge contained in crop growth models with economic considerations and environmental impact assessments (Jame and Cutforth, 1996). DSSAT allows to simulate long-term crop rotation or sequence under different climate scenarios by means of Sequence option that permits to evaluate the effects of rotation on crop yield, soil, water and nutrient status (Thornton $e t$ al., 1994). Thanks of the linkage of DSSAT with a Geographic Information System (GIS), the model can also carry out productivity 
analysis at regionally scale. In fact, several studies have been carried out to examine cropping systems at spatial scale (Rinaldi and Borneo, 2001; Heinemann et al., 2002; Guereña et al., 2001; Luo et al., 2003; Rinaldi et al., 2007; Giglio et al., 2010).

Changes in global average temperature, precipitation regime and increase of atmospheric $\mathrm{CO}_{2}$ concentration will impact the crop productions at various rates in different parts of the world with consequences related to food supply and demand (Rosenzweig and Parry et al., 1994; Olesen and Bindi, 2002; Parry, 2004; Lee, 2009). Furthermore, despite new technologies and introduction of new crop variety, climate will continue to be a predominant effect on the yield response of the crops.

Particularly in the Mediterranean area, already considered as one of the most critical and vulnerable geographic zone, the global warming phenomenon, concerning both the climate characteristics like temperature and precipitation pattern, could affect the water availability and irrigation requirements due to significant variations of evapotraspiration rates, runoff, infiltration and soil moisture temporal dynamics. In fact, the IPCC report (IPCC, 2007a) shows as that Mediterranean climate could be interested by a greater increase of temperature, especially in the summer months although the predictions of rainfall are more uncertain and differentiated on basis of the relationships between local factors as geographic features and land use. Certainly environmental modifications, especially soil moisture and air condition variations have strong influence on the most important plant physiological processes (photosynthesis, transpiration, respiration and partitioning of photosynthesis products). Many studies researches have been carried out to predict the impacts of climate change on crop productivity and to estimate the vulnerability degree of most important crops as wheat, corn, soybean (among others, Alexandrov 1997; Alexandrov and Hoogenboom, 2000; Eitzinger et al., 2003; Ventrella et al., 2008; Guo et al., 2010). Moreover, modifications of these processes can require the individuation of management practices in order to adapt the cropping systems to the forecasted climate condition. Such an optimization can interest important agronomic practices at farm level as crop and/or variety choice, sowing/transplantig time, crop rotation, fertilization, irrigation, wedding control, etc. Ventrella et al. (2011) used the cropping system models CERES-Wheat and CROPGROTomato of DSSAT to analyse the response of winter durum wheat and tomato crops to climate change, irrigation and nitrogen fertilizer managements.

Among the agronomical practices, crop rotation allows to preserve agronomic and environmental sustainability by using more efficiently natural resources and give, in most case, higher crop yields than these obtained in monoculture. Sequence of various crops, other than to avoid the build-up of pathogens and pests problems, is considered to be an useful technique to conserve and to improve soil structure and fertility. On the other hand, the adoption of cereal rotations with other crops, especially with legumes, and incorporating of crop residues, can reduce the amount of mineral nitrogen fertilizers applied to the soil (Shah et al., 2003).

The interest of this study is focused on Capitanata area, a plain of about $4000 \mathrm{~km}^{2}$ located in the northern part of the Apulia Region in southern Italy. Such area is characterized by farms with average size up to 20 ha, highly productive soils cultivated in intensive and irrigated regime. The winter durum wheat (Triticum durum L.) represents the principal cereal crop often grown in rotations with irrigated horticultural species. Among these, processing tomato crop (Lycopersicon aesculentum Mill.) is well represented. In particular, two-years rotation (tomato-wheat) and three-years rotation (tomato-wheat-wheat) are the typical farming rotations of this large productive area.

Our interest was, firstly, to evaluate winter durum wheat and tomato responses under future climatic scenarios as generated by three different climate GCMs (HadCM3, CCSM3, ECHAM5) trough a space-temporal analysis for seven pedologic homogeneous areas characterizing the spatial variability of Capitanata plain. In a second step, only climatic scenarios derived from HadCM3 model were used to compare different hypothesis of crop sequences based on cultivation of winter durum wheat and tomato. The analysis included productive parameters, some water balance components and soil organic matter temporal evolution.

\section{Materials and methods}

\section{Study area}

The Capitanata plain is delimited by the Apennines Chain at West and by Gargano promontory at East and is mainly constituted by continental and fluvial sediments and some terraced marine deposits of Pliocene and Pleistocene ages. The climate of this zone is classified as climate Accentuated Thermo-Mediterranean (UNESCO-FA0), with winter characterized by temperatures that also descend below $0^{\circ} \mathrm{C}$ and hot summer with temperature that can exceed $40^{\circ} \mathrm{C}$. The annual precipitations range between 400 and $800 \mathrm{~mm}$, mostly concentrated in winter months.

Seven homogeneous pedologic areas represent the soil data model inputs (Figure 1a). For each homogeneous area considered, a specific

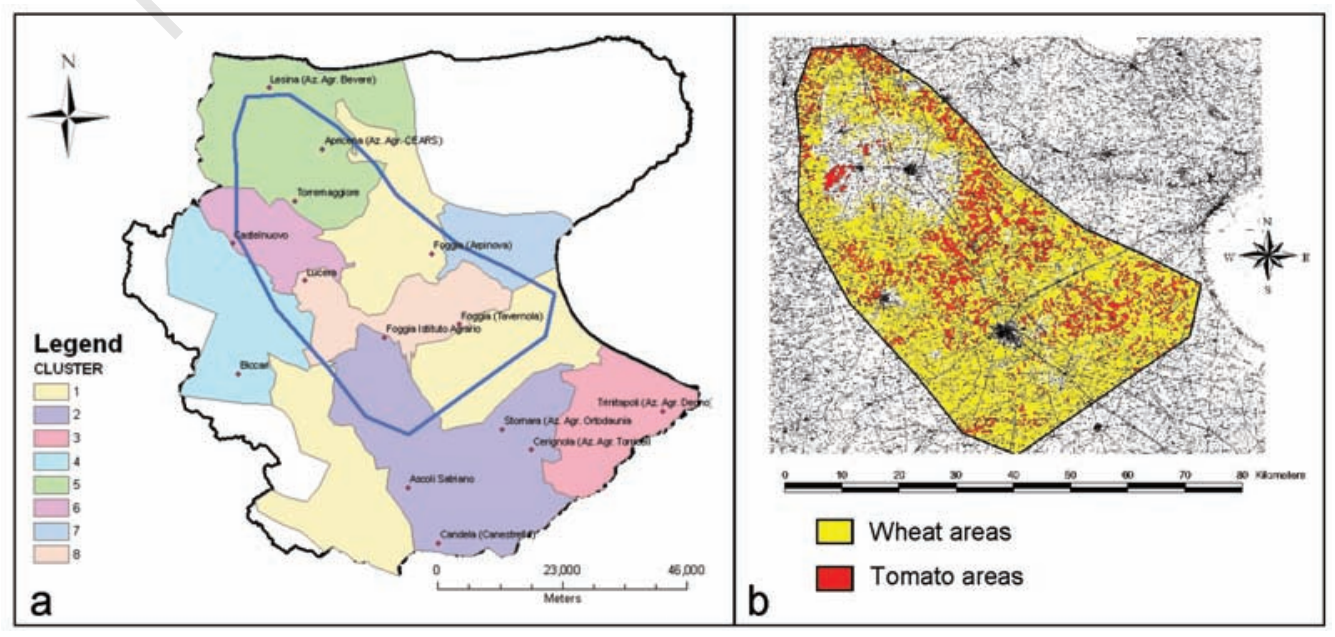

Figure 1. Homogeneous pedologic areas in Capitanata plain (a); Soil use map (b). 
pedologic profile was individuated applying a clustering procedure and a subsequent interpolation of soil data by geostatistical techniques (Castrignanò et al., 2010). Soil profile for each area was subdivided in two layers (0-40 and 41-80 cm) and described by some measured characteristics (texture, soil organic carbon, cation exchange capacity, $\mathrm{pH}$ in water) and hydrological parameters (soil water holding and conductivity), calculated by means of pedotransfer functions implemented into the DSSAT model. Figure 1b shows land use map related to the cultivation of winter durum wheat and tomato. Such map was obtained combining spectral and spatial information relative to the area of study. Fiorentino et al. (2008) integrated a special classifier of remote sensed data, derived from interpretation of Landsat TM image collected in July 2006 , with the spatial information provided by a geostatistical tool as Indicator Kriging algorithm. Some areas, not be classified due to clouds cover, were considered using informations of soil classes as indicated in the SIGRIA CASI 3 Project (INEA, 2001). According to such analysis the winter durum wheat was potentially cultivated in the $90 \%$ of polygons while the remaining $10 \%$ interested the cultivation of tomato.

\section{Climatic scenarios}

Two IPCC future climate scenarios (B1 and A2) were used in order to evaluate the impact of future climate change, taking into account the progressive increase of atmospheric $\mathrm{CO}_{2}$ concentration, respect to the pre-industrial level. The alternative climate projections used in this study were the output data of three GCMs: Hadley Centre Coupled Model version 3 (HadCM3), NCAR's Community Climate System Model version 3 (CCSM3) and a model referred to Max Planck Institute for Meteorology of Hamburg - DE (ECHAM5), as described by Pizzigalli $e t$ al. (2012) and Rinaldi and De Luca (2012). The local interest of this study imposed to use of regional downscaled data at daily temporal scale. A statistical downscaling procedure was conducted using the stochastic weather generator LARS WG, that was calibrated including statistics and changes in mean climate, as derived from GCM, and integrated with the statistics of historical climatic series collected at the experimental farm of Agricultural Resource Council (CRA) at Foggia (Pizzigalli et al., 2012). The obtained future climate scenarios were divided in three time slices (I: 2011-2040; II: 2041-2070 and III: 20712100 ) and compared to a generated baseline scenario (1951-2005). In the second part of this study, only A1 and B2 scenarios generated from HadCM3 were considered to assess the future climate change impacts.

\section{Crop models and management}

DSSAT is a cropping system model allowing to predict and interpret the behaviour of the agronomic system for given condition, reducing the time and human resources necessary to find problem solutions and to evaluate alternative decision in agriculture (Tsuji et al., 1998). The model is characterized by a modular structure that facilitates its maintenance and permits the inclusion of additional components to simulate cropping system over a wide range of soils, climate and manage- ment conditions (Porter et al., 2000; Jones et al., 2003). The DSSAT is a collection of crop simulation models (for more than 20 crops) combined with various module for weather, soil water, soil dynamic, soil temperature, soil nitrogen and carbon and also crop management modules (including planting, harvesting, irrigation, fertilizer and residue). All modules operate together and the crop simulation model is the centre (Tsuji et al., 1998; Hoogenboom et al., 2004). CERES-wheat and CROPGRO-tomato are crop growth models embedded in DSSAT (Jones et al.,2003) that are able to predict the performance of wheat and tomato, respectively. CERES-wheat was tested in different sites in the world (Semenov et al., 1996; Alexandrov, 1997; Eitzinger et al., 2003; Lhomme et al., 2009; Pathak and Wassmann, 2009; Ventrella et al., 2009; Guo et al., 2010). However, CROPGRO model initially was developed for legumes (Boote et al., 1998; Hoogenboom et al., 1994), successively was adapted to tomato. Rinaldi and Ubaldo (2007), Rinaldi et al. (2007) and Giglio et al. (2010) applied such model for tomato cultivation. Both cropping system models have been calibrated and validated, at the selected area and for the two crops object of this study, by using experimental data collected in experimental trials conducted in a farm of CRA at Foggia (Wheat: cv Simeto, Rinaldi, 2001; Tomato: variety PS 1296, Rinaldi et al., 2007). The soil water balance, developed according to the cascading method or the tipping bucket approach, include precipitation, infiltration, transpiration, soil evaporation, drainage from the soil profile and crop water uptake parameters; whereas potential evapotraspiration is calculated using modified version of Priestley Taylor (1972) method. In addition, through the organic matter turnover, the crop models evaluate carbon and nitrogen balances providing feedback that influences various growth and development processes. The CENTURY-based module, used in this study, was adapted by Gijsman et al. (2002) and integrated into the DSSAT structure (Jones et al., 2003) to facilitate the simulation of potential soil organic carbon sequestrations in crop rotations, initializing soil carbon and other variables only at the start of the simulations. The incorporation of the CENTURY-based module has make DSSAT more flexible in handling different agricultural systems and more suitable for long-term simulations.

The main crop management practices, reported in Table 1, were scheduled to preserve optimum conditions according to the agronomic practices currently adopted in the Capitanata plain. For tomato growth automatic irrigation was adopted, setting a drip irrigation method, with water amount refilling up to $80 \%$ of field capacity and irrigation with the soil moisture falling to $60 \%$ of field capacity.

The AEGIS/WIN option, as described by Engel et al. (1997), was applied with polygons derived by the intersections of soil and land-use as reported in Figure 1 for winter durum wheat and tomato. The simulation outputs were also displayed in thematic digital maps for better visualization of spatial analysis (data not shown).

For the each homogeneous areas, the Sequence option was used in order to simulate a two-years (wheat-tomato) and a three-years (wheat-wheat-tomato) crop rotations, compared to a continuous cultivation of wheat.

Table 1. Crop management of winter durum wheat and tomato.

\begin{tabular}{lll}
$\begin{array}{ll}\text { Management } \\
\text { Sowing/transplanting }\end{array}$ & $\begin{array}{l}\text { Winter durum wheat } \\
26^{\text {th }} \text { November }\end{array}$ & $\begin{array}{l}\text { Tomato } \\
30^{\text {th }} \text { April }\end{array}$ \\
$\begin{array}{ll}\text { Fertilization } \\
\mathrm{N}\end{array}$ & $60 \mathrm{~kg} \mathrm{ha}^{-1}$ as diammonium phosphate (pre-sowing) & $100 \mathrm{~kg} \mathrm{ha}^{-1}$ as diammonium phosphate (pre-transplanted) \\
& $60 \mathrm{~kg} \mathrm{ha}^{-1}$ as ammonium nitrate (top dressing) & $\begin{array}{l}100 \mathrm{~kg} \mathrm{ha}^{-1} \text { as ammonium nitrate (top dressing) } \\
\text { Incorporation }\end{array}$ \\
$\begin{array}{ll}\text { Crop residues } \\
\text { Inrigation }\end{array}$ & Rainfed & Automatic \\
\hline Harvest & At maturity & At maturity \\
\hline
\end{tabular}




\section{Results and discussion}

\section{Climate data analysis}

Compared to Baseline, in $\mathrm{B} 1$ scenario the mean annual $\left(\mathrm{T}_{\text {avg }}\right)$ was projected to increase from $0.8^{\circ} \mathrm{C}$ to $1.6^{\circ} \mathrm{C}$ from 2011 to 2100 . A similar trend was also observed for the annual $\mathrm{T}_{\text {avg }}$ in $\mathrm{A} 2$ scenario but with higher values ranging from $0.7^{\circ} \mathrm{C}$ to $2.7^{\circ} \mathrm{C}$. Instead, an increase in rainfall was predicted of about 5 and $9 \%$ for B1 and A2 scenarios, respectively, without particular temporal trend (Table 2).

\section{Crop vulnerability to climate change and GCMs com- parison}

The dry matter grain yield of winter durum wheat was about $3.60 \mathrm{t}$ $\mathrm{ha}^{-1}$. Under the forecasted climate scenarios, a slight increase of $4 \%$ was observed in average without significant differences due to the effect of different GCMs but also of IPCC scenarios (Figure 2), in agreement with the results obtained by Guo et al. (2010) as a consequence of a overall effect due to increasing temperatures, raising $\mathrm{CO}_{2}$ and with no significant variations of annual precipitation.

Other studies reported that elevated $\mathrm{CO}_{2}$ concentration can have considerable effects on wheat yield (Reyenga et al., 2001; Weiss et al., 2003). However, Rosenzweig and Tubiello (1996) found inconsistence in wheat yield changes under doubling of $\mathrm{CO}_{2}$ and a rise in daily average temperature. Haim et al. (2008) excluded the effect of $\mathrm{CO}_{2}$ fertilization on wheat yield to avoid the uncertainty when combined with other environmental parameters. The behaviour of tomato crop, cultivated in the spring-summer period, was completely different if compared to winter durum wheat with the forecasted increase of seasonal temperature affecting negatively the crop performances. In particular, results reported in Figure 3 shown that the reference dry matter fruit yield simulated for tomato in Baseline period was $11.73 \mathrm{t} \mathrm{ha}^{-1}$. Under future climate, yield decreased slightly in the first and second 30 -year periods $(-6 \%)$, and strongly in the last 30 -year period (from 2070 to 2100) (-24\%). In particular, under A2 scenario of HadCM3, a more significant decrease of tomato yield (-38\%) was predicted during the third 30 -year period. This large yield decline was due to the greater temperature increase observed in the future scenarios respect to the Baseline during growth season (April-August) and in particular during the reproductive stage with negative consequences in the development rate and the photosynthates translocation into the fruits. Such significant decrease of tomato dry matter yield due to the rising temperature was not fully offset by the positive effect expected by increasing $\mathrm{CO}_{2}$. The results of irrigation requirement, simulated only for tomato under different climate change scenarios compared with the baseline period, are reported in Figure 4 showing an average value of about $310 \mathrm{~mm}$ for the Baseline scenario. Due to different rainfall distribution and evaporative demand of the atmosphere simulated by CGMs, significant differences were observed with the HadCM3 predicting seasonal irrigation higher than those of the other GCMs with increments ranging from 5-15\% (Figure 4).

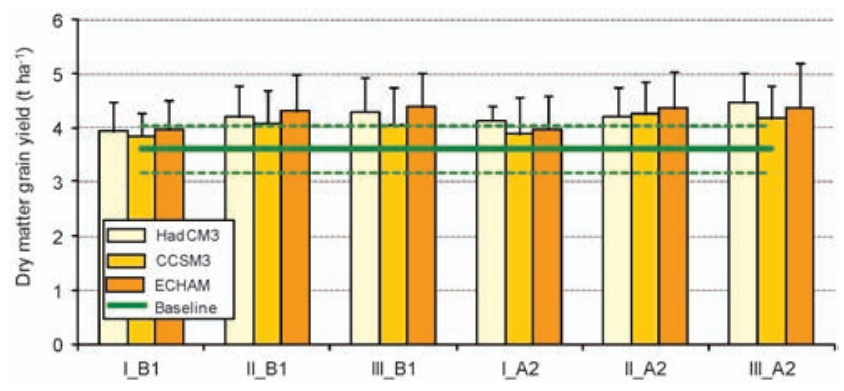

Figure 2. Comparison between output of dry matter grain yield of winter durum wheat obtained using three future climatic models (during three 30-year periods) and Baseline scenario.

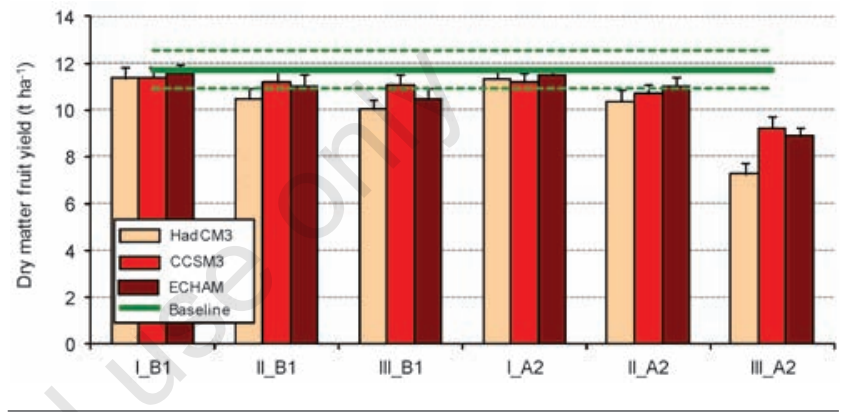

Figure 3. Comparison between output of dry matter fruit yield tomato obtained using three future climatic models (during three 30 -year periods) and Baseline scenario.

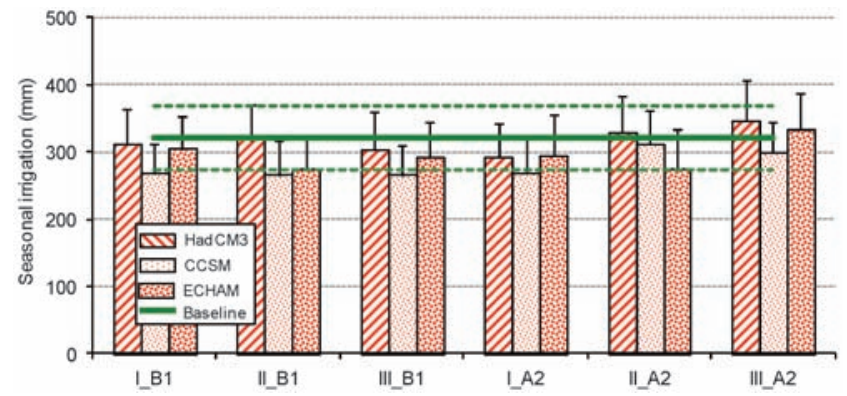

Figure 4. Comparison between output of tomato seasonal irrigation simulated using three future climatic models (during three 30-year periods) and Baseline scenario.

Table 2. Baseline scenarios and change of temperature and precipitation under B1 and A2 scenarios and atmospheric $\mathrm{CO}_{2}$ concentration.

\begin{tabular}{|c|c|c|c|c|c|c|c|c|c|}
\hline & $\begin{array}{l}\text { Precipitation } \\
\text { (mm) }\end{array}$ & ${ }^{\mathrm{T}_{\text {avg }}}$ & $\mathrm{CO}_{2}$ & $\begin{array}{c}\text { B1 } \\
\text { Precipitation } \\
(\Delta \%)\end{array}$ & $\begin{array}{l}\mathrm{T}_{\text {avg }} \\
\Delta^{\circ} \mathrm{C}\end{array}$ & $\mathrm{CO}_{2}$ & $\begin{array}{c}\text { A2 } \\
\text { Precipitation } \\
(\Delta \%)\end{array}$ & $\begin{array}{l}\mathrm{T}_{\text {avg }} \\
\Delta^{\circ} \mathrm{C}\end{array}$ & $\mathrm{CO}_{2}$ \\
\hline Baseline & 632 & 15.5 & 360 & & & & & & \\
\hline 2011-2040 & & & & 4.7 & 0.80 & 400 & 10.5 & 0.68 & 400 \\
\hline 2041-2070 & & & & 4.9 & 1.26 & 500 & 8.3 & 1.58 & 550 \\
\hline $2071-2100$ & & & & 5.7 & 1.63 & 550 & 9.7 & 2.71 & 750 \\
\hline
\end{tabular}




\section{Cropping systems simulations adopting HadCM3 model outputs}

The results discussed in this section are those obtained by considering only HadCM3 and adopting the sequence option of DSSAT in order to evaluate the effects of crop rotation, climate change, spatial variability and their interactions on winter durum wheat and tomato productivity. Also in this case, the average yields of winter wheat and tomato simulated under Baseline scenario were comparable to those generally obtained in the study area of Capitanata.

\section{Winter durum wheat}

All the parameters analysed revealed that the effects of crop rotation, climate change, spatial variability, as well as their respective interactions, were highly significant (Table 3). Crop rotation showed that the two-year and three-year rotations increased the winter durum wheat yield of about 20 and $10 \%$, respectively, compared to the durum wheat monoculture. The same trend was observed for crop evapotranspiration (ET), water use efficiency (WUE) and Nitrogen (N) uptake. Changes in temperature, precipitation and $\mathrm{CO}_{2}$ concentration were predicted to increase the grain yield of about $15 \%$ and $20 \%$ under $\mathrm{B} 1$ and $\mathrm{A} 2$, respectively, with the same trends also for the other parameters with the exception of harvest index (HI) that showed small variations. Such last result can be attributed to a lower increment of total biomass respect to that of grain yield.

The spatial variability, as represented by the 7 homogeneous areas, was the factor variability with the lowest variations for the all parameters (Table 3). When crop rotation and climate scenario in the Baseline and future periods were considered the trends, just observed as main effects, were confirmed with the highest yield characterizing the twoyear rotation and the future scenario. In particular, the mean grain yield in one-year rotation was always lower than $4 \mathrm{tha}^{-1}$, confirming the validity to adopt crop rotations including the irrigated tomato. Moreover, regardless of crop rotation, the wheat yield was predicted to increase almost linearly during the future study period. A particularly high increment (more than 20\%) was observed in the first 30-year period compared to the Baseline one when the three-year rotation was considered (Figure 5).

Durum wheat seasonal evapotraspiration was predicted to increase for all crop rotations during the future periods compared to the Baseline one either for A2 and B1 scenarios (Figure 6). This finding that would lead to increase evapotranspiration, exceeding an average value of $400 \mathrm{~mm}$, is due to highest evaporative demand of the atmosphere caused by the rise of temperature during the spring months.

Also the durum wheat $\mathrm{N}$ uptake was predicted to increase during the future period and in particular for the two-year and three-year rotation with values higher than $150 \mathrm{~kg} \mathrm{ha}^{-1}$ (Figure 7).

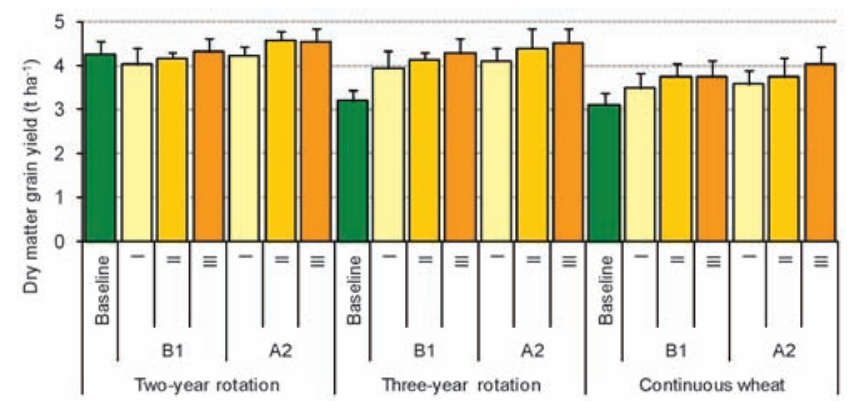

Figure 5. Effects of interactions between climatic scenarios and crop rotations on dry matter grain yield of winter durum wheat.

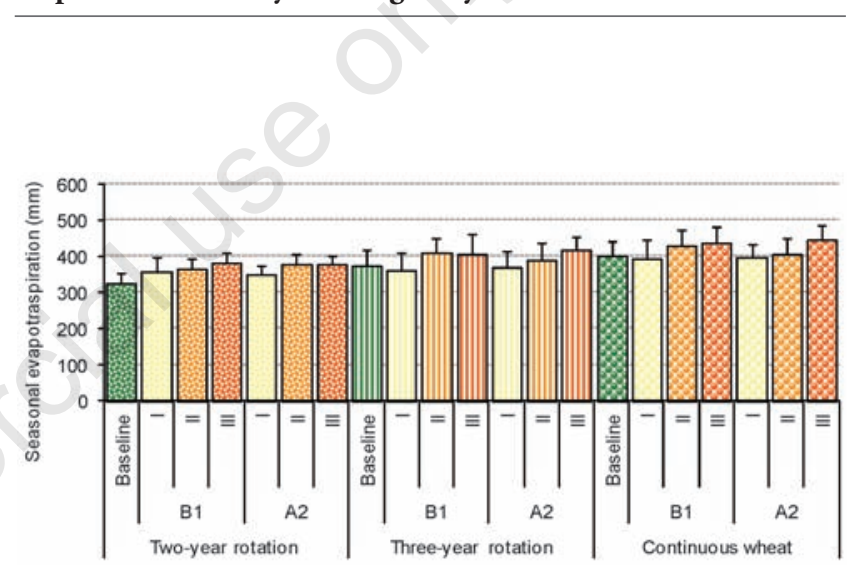

Figure 6. Effects of interactions between climatic scenarios and crop rotations on seasonal evapotranspiration of winter durum wheat.

Table 3. Results of main effects, as average \pm standard deviation, on winter durum wheat parameters simulated by CERES-wheat model.

\begin{tabular}{|c|c|c|c|c|c|}
\hline & $\begin{array}{l}\text { Yield } \\
\left(\mathrm{t} \mathrm{ha}^{-1}\right)\end{array}$ & HI & $\begin{array}{c}\text { ET } \\
(\mathrm{mm})\end{array}$ & $\begin{array}{c}\text { WUE } \\
\left(\mathrm{kg} \mathrm{m}^{-3}\right)\end{array}$ & $\begin{array}{l}\text { Nitrogen uptake } \\
\left(\mathrm{kg} \mathrm{ha}^{-1}\right)\end{array}$ \\
\hline \multicolumn{6}{|l|}{ Crop management } \\
\hline One-year rotation & $3.58 \pm 0.46$ & $0.39 \pm 0.05$ & $415 \pm 46$ & $0.87 \pm 0.12$ & $132 \pm 13$ \\
\hline Two-year rotation & $4.30 \pm 0.33$ & $0.39 \pm 0.04$ & $359 \pm 35$ & $1.21 \pm 0.14$ & $158 \pm 09$ \\
\hline Three-year rotation & $3.99 \pm 0.57$ & $0.40 \pm 0.05$ & $388 \pm 49$ & $1.04 \pm 0.17$ & $147 \pm 17$ \\
\hline \multicolumn{6}{|l|}{ Climate } \\
\hline Baseline & $3.41 \pm 0.49$ & $0.39 \pm 0.05$ & $374 \pm 50$ & $0.93 \pm 0.24$ & $129 \pm 18$ \\
\hline B1 & $3.92 \pm 0.42$ & $0.39 \pm 0.05$ & $401 \pm 52$ & $0.99 \pm 0.16$ & $144 \pm 13$ \\
\hline A2 & $4.11 \pm 0.48$ & $0.40 \pm 0.04$ & $398 \pm 46$ & $1.05 \pm 0.18$ & $149 \pm 16$ \\
\hline \multicolumn{6}{|l|}{ Areas } \\
\hline Area 1 & $3.95 \pm 0.53$ & $0.40 \pm 0.05$ & $394 \pm 50$ & $1.02 \pm 0.19$ & $146 \pm 16$ \\
\hline Area 2 & $3.84 \pm 0.55$ & $0.39 \pm 0.05$ & $391 \pm 49$ & $1.00 \pm 0.20$ & $141 \pm 17$ \\
\hline Area 4 & $3.82 \pm 0.56$ & $0.40 \pm 0.05$ & $391 \pm 51$ & $0.99 \pm 0.20$ & $141 \pm 17$ \\
\hline Area 5 & $3.77 \pm 0.58$ & $0.40 \pm 0.05$ & $389 \pm 51$ & $0.99 \pm 0.20$ & $138 \pm 18$ \\
\hline Area 6 & $3.89 \pm 0.55$ & $0.39 \pm 0.05$ & $398 \pm 50$ & $0.99 \pm 0.19$ & $142 \pm 13$ \\
\hline Area 7 & $3.96 \pm 0.52$ & $0.39 \pm 0.05$ & $396 \pm 50$ & $1.02 \pm 0.19$ & $145 \pm 16$ \\
\hline Area 8 & $3.90 \pm 0.53$ & $0.39 \pm 0.05$ & $397 \pm 49$ & $1.00 \pm 0.19$ & $143 \pm 17$ \\
\hline
\end{tabular}

$\mathrm{HI}$, harvest index; ET, evapotraspiration; WUE, water use efficiency; all the effects, as well as their respective interactions, are highly significant. 


\section{Tomato}

All the parameters analysed revealed that the effects of crop rotation, climate change and spatial variability, as well as their respective interactions, were highly significant as reported for durum wheat. However, the two-year rotation improved tomato yields by only $4 \%$ compared to the three-year rotation (Table 4). The only exception was related to $\mathrm{N}$ uptake that showed a reduction of about $12 \%$ in the three-year rotation because of a likely higher $\mathrm{N}$ uptake of winter durum wheat which could require an higher $\mathrm{N}$ fertilization than that planned in the carried out simulation. The spatial variability slightly affected the tomato parameters with the exception of $\mathrm{N}$ uptake that showed variation up to $13 \%$ due to the different nitrogen availability that characterize the seven soil (Table 4). Under the future climate scenarios, the model simulated negative effects on tomato yield. A decrease in fruit dry matter of $40 \%$ and $46 \%$ approximately was detected in the B1 and A2 scenarios, respectively. Similar trends were also observed for HI and WUE. Moreover, an increase of ET and N uptake was predicted for future scenarios but with variations that did not exceed 5\% (Table 4). Figure 8 shows the effects of the interaction Climate $x$ Crop rotation on tomato fruit yield. The Baseline dry matter fruit yield predicted for tomato cultivated in two-year rotation was about $14 \mathrm{t} \mathrm{ha}^{-1}$, while, in three-year rotation such parameter dropped to $12 \mathrm{t} \mathrm{ha}^{-1}$. Under future climate, yield was predicted to decrease over all in the last 30 -year period of this century taking lower values about 6 and $4 \mathrm{tha}^{-1}$ under B1 and $\mathrm{A} 2$ scenarios, respectively, regardless of crop rotation. The reference irrigation requirement for tomato was about $350 \mathrm{~mm}$. No large differences were predicted when the tomato was included in the two-year rotation. However, DSSAT simulated decreasing irrigation requirements in the future study period up to $250-300 \mathrm{~mm}$ when tomato was cultivated in 3 -year rotation (Figure 9). This result is probably due to residual effects of soil water content at transplanting time of tomato when the three-year rotation was adopted

The simulation of $\mathrm{N}$ uptake highlighted an increase that characterize the two-year rotation compared to the Baseline with the $\mathrm{N}$ uptake reaching the threshold value of $500 \mathrm{~kg} \mathrm{ha}^{-1}$ under A2 scenario (Figure $10)$. The strong increase of $\mathrm{N}$ uptake coupled with equally strong reduction in yield caused a consequent a sharp reduction in nitrogen use efficiency.

\section{Soil organic matter trends}

DSSAT with the CENTURY-module displays a greater flexibility in handling different agricultural systems and has become more suitable for long-term simulations (Gijsman et al., 2002).

Figures 11 and 12 report the temporal evolution of total soil organic carbon (C) and total soil organic nitrogen during the study period

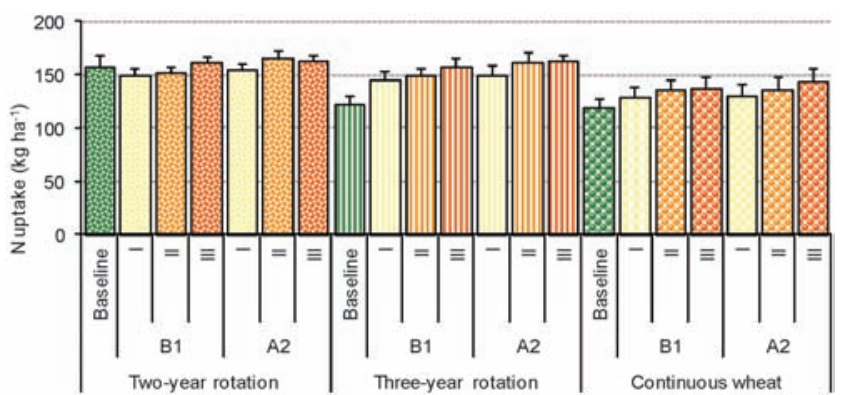

Figure 7. Effects of interactions between climatic scenarios and crop rotations on seasonal $\mathrm{N}$ uptake of winter durum wheat.

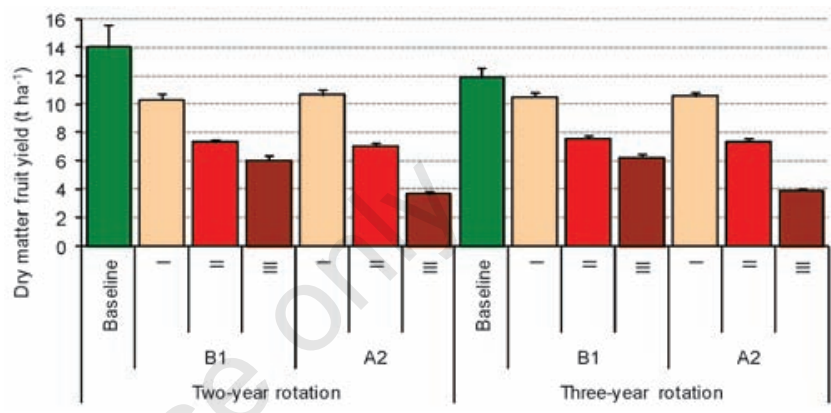

Figure 8. Effects of interactions between climatic scenarios and crop rotations on dry matter fruit yield options of tomato.

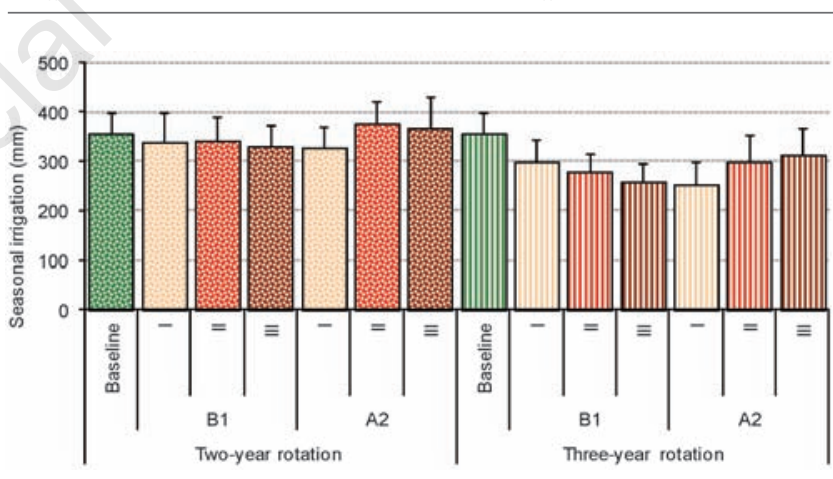

Figure 9. Effects of interactions between climatic scenarios and crop rotations on seasonal irrigation of tomato.

Table 4. Main effect results, as average \pm standard deviation, on tomato parameters simulated by CROPGRO-tomato model.

\begin{tabular}{|c|c|c|c|c|c|}
\hline Tomato & $\begin{array}{c}\text { Yield } \\
(\mathrm{t} \mathrm{ha-1})\end{array}$ & HI & $\begin{array}{c}\text { ET } \\
(\mathrm{mm})\end{array}$ & $\begin{array}{c}\text { WUE } \\
\left(\mathrm{kg} \mathrm{m}^{-3}\right)\end{array}$ & $\begin{array}{l}\text { Nitrogen uptake } \\
\left(\mathrm{kg} \mathrm{ha}^{-1}\right)\end{array}$ \\
\hline $\begin{array}{l}\text { Crop management } \\
\text { Two-year rotation } \\
\text { Three-year rotation }\end{array}$ & $\begin{array}{l}8.99 \pm 3.59 \\
8.61 \pm 2.76\end{array}$ & $\begin{array}{l}0.53 \pm 0.13 \\
0.55 \pm 0.14\end{array}$ & $\begin{array}{l}817 \pm 59 \\
814 \pm 52\end{array}$ & $\begin{array}{l}1.12 \pm 0.46 \\
1.07 \pm 0.36\end{array}$ & $\begin{array}{l}465 \pm 71 \\
409 \pm 58\end{array}$ \\
\hline $\begin{array}{l}\text { Climate scenarious } \\
\text { Baseline } \\
\text { B1 } \\
\text { A2 }\end{array}$ & $\begin{array}{r}13.16 \pm 1.68 \\
7.91 \pm 1.80 \\
7.09 \pm 2.81 \\
\end{array}$ & $\begin{array}{l}0.70 \pm 0.13 \\
0.52 \pm 0.04 \\
0.46 \pm 0.05\end{array}$ & $\begin{array}{l}809 \pm 48 \\
813 \pm 53 \\
822 \pm 64\end{array}$ & $\begin{array}{l}1.63 \pm 0.22 \\
0.98 \pm 0.26 \\
0.89 \pm 0.39\end{array}$ & $\begin{array}{l}424 \pm 75 \\
444 \pm 62 \\
452 \pm 76\end{array}$ \\
\hline $\begin{array}{l}\text { Areas } \\
\text { Area } 1 \\
\text { Area } 2 \\
\text { Area } 4 \\
\text { Area } 5 \\
\text { Area } 6 \\
\text { Area } 7 \\
\text { Area } 8\end{array}$ & $\begin{array}{l}8.80 \pm 3.45 \\
8.88 \pm 3.24 \\
8.80 \pm 3.22 \\
8.75 \pm 3.11 \\
8.84 \pm 3.31 \\
8.86 \pm 3.42 \\
8.88 \pm 3.30\end{array}$ & $\begin{array}{l}0.54 \pm 0.14 \\
0.54 \pm 0.13 \\
0.54 \pm 0.13 \\
0.54 \pm 0.13 \\
0.54 \pm 0.14 \\
0.54 \pm 0.14 \\
0.54 \pm 0.13\end{array}$ & $\begin{array}{l}816 \pm 57 \\
813 \pm 56 \\
816 \pm 57 \\
816 \pm 57 \\
816 \pm 57 \\
816 \pm 57 \\
816 \pm 57\end{array}$ & $\begin{array}{l}1.10 \pm 0.45 \\
1.11 \pm 0.42 \\
1.09 \pm 0.42 \\
1.09 \pm 0.41 \\
1.10 \pm 0.43 \\
1.10 \pm 0.44 \\
1.10 \pm 0.43\end{array}$ & $\begin{array}{l}486 \pm 62 \\
421 \pm 59 \\
430 \pm 71 \\
406 \pm 71 \\
443 \pm 74 \\
476 \pm 64 \\
436 \pm 62\end{array}$ \\
\hline
\end{tabular}

HI, harvest index; ET, evapotraspiration; WUE, water use efficiency; all the effects, as well as their respective interactions, are highly significant. 
under Baseline and future scenarios for the three crop rotations. The higher values of soil organic $\mathrm{C}$ and $\mathrm{N}$ were observed in two- and threeyear crop rotations than in the durum wheat monoculture. This trend was evident over the years of the Baseline scenario and continued in the future scenarios. The higher $\mathrm{C}$ and $\mathrm{N}$ soil content in the two-year rotation can be attributed to the higher production of crop tomato residues that characterized this rotation compared to the other ones. In particular, the tomato returning most frequently on the soil increased

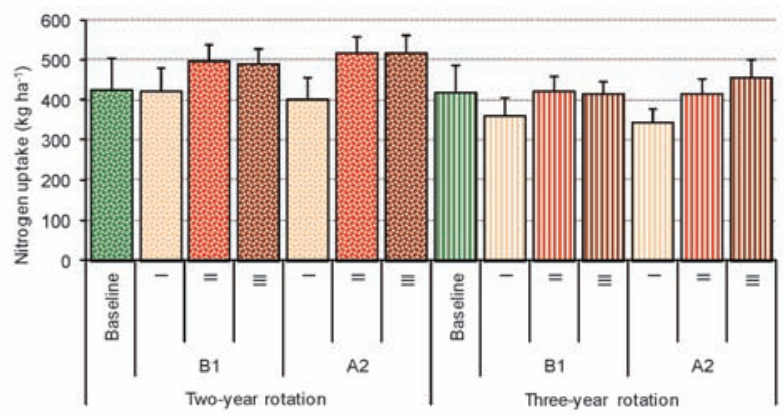

Figure 10. Effects of interactions between climatic scenarios and crop rotations nitrogen uptake of tomato.

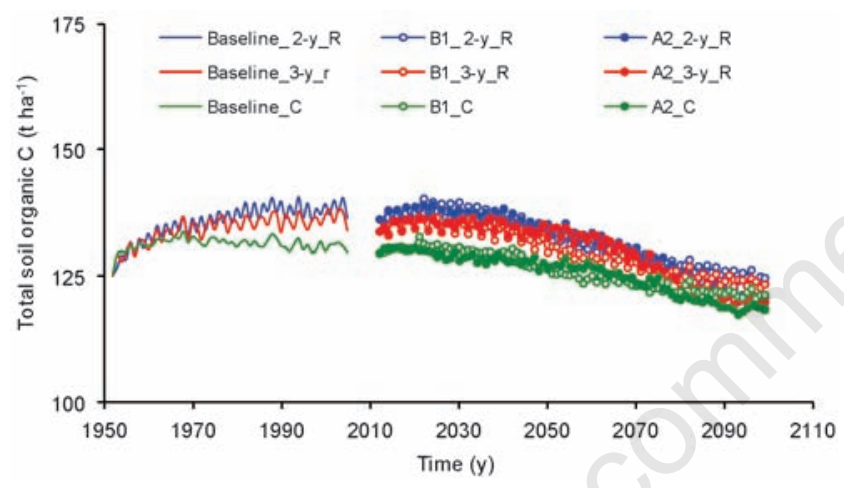

Figure 11. Total soil organic carbon trends considering for crop rotations $\left(C=\right.$ continuous wheat; $2-y_{-} R=$ two-year rotation; 3$\mathbf{y}_{-} \mathbf{R}=$ three-year rotation) under climate scenarios (Baseline, B1 and A2).

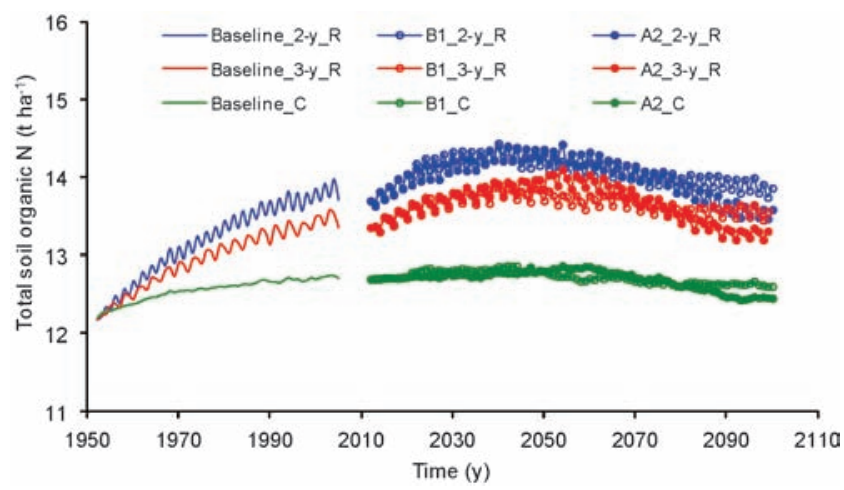

Figure 12. Total soil organic nitrogen trends considering for crop rotations $\left(C=\right.$ continuous wheat; $2-y_{-} R=$ two-year rotation; 3$\mathbf{y} \_\mathbf{R}=$ three-year rotation) under climate scenarios (Baseline, B1 and A2). the biomass useful for humification processes.

In the Baseline scenario and during the first ten years, $\mathrm{C}$ and $\mathrm{N}$ contents increased in all crop rotations. After this period, the contents of $\mathrm{C}$ stabilized around $130 \mathrm{t} \mathrm{ha}^{-1}$ while those of the two- and three-year rotation continued to increase up to $140 \mathrm{t} \mathrm{ha}^{-1}$. Such values remained almost constant for the next 40 years and then began to decrease reaching new steady-state values at the end of the century (between 120 and $130 \mathrm{t} \mathrm{ha}^{-1}$ of $\mathrm{C}$ soil, Figure 11). Such decline of $\mathrm{C}$ content during future scenarios can be attributed to the higher temperature that increased the degradation of the soil organic C. Figure 12, related to soil organic N, showed the same temporal evolutions but with larger differences depending on crop rotations.

In future scenarios, applying the rotation techniques, trends of soil $\mathrm{C}$ and $\mathrm{N}$ content, slightly ascend until the first 30 -year period, successively decrease progressively during the second and the third 30 -year periods, reaching values more lower than observed in the baseline only for soil $\mathrm{C}$ content.

\section{Conclusions}

Climate change impact is today a basic concern of great interest at local and international levels. The combination of generated climatic scenarios with crop simulation models, represents operative tools able to project hypothesis for the future and improving the research capability. The comparison between GCMs showed no significant differences for winter durum wheat yield, while noticeable differences were found for the tomato yield and irrigation requirements. The differences between winter and summer crops on the fitting capacity respect to climate change depended on the timing and the duration of vegetative and reproductive phases that were determinant for yield. The simulations for winter durum wheat showed that, under future IPCC scenarios, the positive fertilization effect of increasing $\mathrm{CO}_{2}$ concentration on yields was greater than the negative effects due to rising temperature and variation of rainfall. These results were in agreement with those reported in the FARIPCC report (IPCC, 2007b). For winter durum wheat the simulation highlighted that two- and three-year rotations including one year of tomato cultivation had positive effects on the cereal performances and these effects maintained their efficacy also in future scenarios. However, higher productions of durum winter wheat as simulated during future scenarios and with two-year rotation resulted in greater requirements in terms of both water transpirated and $\mathrm{N}$ uptake.

Instead, for tomato the positive effect of increasing $\mathrm{CO}_{2}$ concentration was not sufficient to overcome the negative effects due to increasing temperatures. These results confirm that summer crops, including tomato, may be strongly affected by climate change. The modification of present crop rotations was found to be not effective enough to reduce the negative effects of climate change even if positive effects were found for maintaining or increasing the soil organic carbon and nitrogen content. Even for the cultivation of tomato, but despite the lower production as forecasted for this crop under future scenarios, the requirement of water for evapotranpiration and nitrogen uptake increased compared to Baseline scenario with consequent negative reductions of water use efficiency and nitrogen use efficiency.

\section{References}

Alexandrov VA, 1997. Vulnerability of agronomic systems in Bulgaria. Climatic Change 36:135-149.

Alexandrov VA, Hoogenboom G, 2000. The impact of climate variability and change on crop yield in Bulgaria. Agricultural and forest mete- 
orology 104:315-327.

Boote KJ, Jones JW, Hoogenboom G, 1998. Simulation of crop growth: CROPGR0 model. In R.M. Peart and R.B. Curry (eds.) Agricultural System Modelling and Simulation. Marcel Dekker Ed., New York, NY, USA, pp 651-692.

Castrignanò A, De Benedetto D, Girone G, Guastaferro F, Sollito D, 2010. Characterization, delineation and visualization of AgroEcozones Using Multivariate Geographical Clustering. Ital. J. Agron. 5:121-132.

Eitzinger J, Štastná M, ŽAlud Z, Dubrovsky M, 2003. A simulation study of the effect of soil water balance and water stress on winter wheat production under different climate change scenarios. Agr. Water Manage. 61:195-217.

Engel T, Hoogenboom G, Jones JW, Wilkens PW, 1997. AEGIS/WIN: a computer program for the application of crop simulation models across geographic areas. Agron. J. 89:912-928.

Fiorentino C, Tarantino C, Castrignanò A, Pasquariello G, 2008. Geostatistics and remote sensing: an improvement in image classification. Proc. Global Workshop on Digital Soil Mapping: Bridging Research, Production, and Environmental Application, Logan, UT, USA.

Giglio L, Chafferdine M, Lopez R, Sollito D, Ventrella D, Ruggeri S, Rinaldi M, Castrignanò AM, 2010. Analisi spazio-temporale degli effetti dei cambiamenti climatici su frumento e pomodoro in Capitanata. pp 13-14 in Atti del XXIII Conv. Naz. di Agrometeorologia, Bari, Italy.

Gijsman AJ, Hoogenboom G, Parton WJ, Kerridge PC, 2002. Modifying DSSAT for low input agricultural systems, using a soil organic matter-residues module from CENTURY. Agron. J. 94:462-474.

Guereña A, Ruiz-Ramos M, Diaz-Ambrona CH, Conde JR, Minguez MI, 2001. Assessment of climate change and agriculture in Spain using climate models. Agron. J. 93:237-249.

Guo R, Lin Z, Mo X, Yang C, 2010. Responses of crops yield and water use efficiency to climate change in the North China Plain. Agr. Water Manage. 97:1185-1194.

Haim D, Shechter M, Berliner P, 2008. Assessing the impact of climatic change on representative field crops in Israeli agriculture: a case study of wheat and cotton. Climatic Change 86:425-440.

Heinemann AB, Hoogenboom G, de Faria RT, 2002. Determination of spatial water requirements at county and regional levels using crop models and GIS. An example of the State of Parana, Brazil. Agr. Water Manage. 52:177-196.

Hoogenboom G, Jones JW, Wilkens PW, Bachelor WD, Bowen WT, Hunt LA, Pickering NB, Singh U, Godwin DC, Baer B, Boote KJ, Ritchie JT, White JW, 1994. Crop models. pp 95-244 in: G.Y. Tsuji, G. Uehara and S. Balas (eds.). DSSAT Ver. 3, vol. 2., University of Hawaii Publ., Honolulu, HI, USA, 95-244.

Hoogenboom G, Jones JW, Wilkens PW, Porter CH, Batchelor WD, Hunt LA, Boote KJ, Singh U, Uryasev 0, Bowen WT, Gijsman AJ, du Toit AS, White JW, Tsuji GY, 2004. Decision support System of Agrotechnology Transfer Version 4.0 (CD-ROM). University of Hawaii Publ., Honolulu, HI, USA.

INEA, 2001. Studio sull'uso irriguo della risorsa idrica nelle regioni Obiettivo 1. Progetto CASI 3. Available from: http://inea.it/irri/

Intergovernmental Panel on Climate Change, 2000. Special report on emission scenarios. Cambrige University Press, Cambrige, UK.

Intergovernmental Panel on Climate Change, 2007a. Climate Change 2007: The Physical Science Basis. Contribution of Working Group I to the Fourth Assessment Report of the Intergovernmental Panel on Climate Change. Cambridge University Press, Cambridge, UK.

Intergovernmental Panel on Climate Change, 2007b. Climate Change 2007: Impacts, Adaptation and Vulnerability. Contribution of Working Group II to the Fourth Assessment Report of the Intergovernmental Panel on Climate Change. Cambridge
University Press, Cambridge, UK.

Jame YW, Cutforth HW, 1996. Crop grow models for decision support systems. Can. J. Plant Sci. 76:9-19.

Jones JW, Hoogenboom G, Porter CH, Boote KJ, Batchelor WD, Hunt LA, Wilkens PW, Singh U, Gijsman AJ, Ritchie JT, 2003. The DSSAT cropping system model. Eur. J. Agron. 2:235-265.

Lee HL, 2009. The impact of climate change on global food and demand, food prices, and land use. Paddy Water Environ. 7:321-331.

Lhomme JP, Mougou R, Mansour M, 2009. Potential impact of climate change on durum wheath cropping in Tunisia. Climatic Change 96:549-564.

Luo Q, William AJ, Bellotti W, Bryan B, 2003. Qunatitative and visual assessment of climate change impacts on South Australian wheat production. Agricultural Systems 77:173-186.

Olesen JE, Bindi M, 2002. Consequences of climate change for European agricultural productivity, land use and policy. Eur. J. Agron. 16:239-262.

Parry ML, Rosenzweig C, Iglesias A, Livermored M, Fischer G, 2004. Effects of climate change on global food production under SRES emission and socio-economic scenarios. Global Environ. Change 14:53-67.

Pathak H, Wassmann R, 2009. Quantitative evaluation of climatic variability and risks for weat yield in India. Climatic Change 93:157175.

Pizzigalli C, Palatella L, Zampieri M, Lionello P, Miglietta MM, Paradisi $\mathrm{P}, 2012$. Dynamical and statistical downscaling of precipitation and temperature in a Mediterranean area. Ital. J. Agron. 7:e2.

Porter C, Jones JW, Braga R, 2000. An approach for modular crop model development. Int. Consortium for Agricoltural Sistems Applications, Honolulu, HI, USA. Available from http://www.icasanet.org/modular/index.html.

Priestley CHB, Taylor RJ, 1972. On assessment of surface heat flux and evaporation using large-scale parameters. Mon. Wheather Rev. 100:81-92.

Reyenga PJ, Howden SM, Meinke H, Hall WB, 2001. Global impacts on wheat production along an environmental gradient in south Australia. Environ. Int. 27:195-200.

Rinaldi M, 2001. Durum wheat simulation in southern Italy using CERES-Wheat model. I. Calibration and validation. pp 81-82 in Proc. 2nd Int. Symp. on Modelling Cropping Systems, Florence, Italy.

Rinaldi M, Borneo V, 2001. Descrizione delle funzionalità di AEGISWIN, interfaccia GIS del software di simulazione colturale DSSAT. Un caso studio in Capitanata. Riv. Ital. Agrometeorol. 2:34-47.

Rinaldi M., De Luca D. 2012. Application of EPIC model to assess climate change impact on sorghum in Southern Italy. Italian Journal of Agronomy. Ital. J. Agron. 7:e12.

Rinaldi M, Ubaldo R, 2007. Simulation at regional level of irrigated wheat and tomato in a Mediterranean environment. Water Res. Manage. 4:569-581.

Rinaldi M, Ventrella D, Gagliano C, 2007. Comparison of nitrose and irrigation strategies in tomato using CROPGRO model. A case study from Southern Italy. Agr. Water Manage. 87:91-105.

Rinaldi M, Vonella AV, Ubaldo R, Garofalo P, Ruggieri S, 2007. La simulazione dei sistemi colturali a scala territoriale. pp 147-162 in Atti Progetto AQUATER, Bari, Italy.

Rosenzweig C, Parry MR, 1994.Potential impact of climate change on world food supply. Nature 367:133-138.

Rosenzweig C, Tubiello FN, 1996. Impacts of global climate change on Mediterranean agriculture: current methodologies and future directions. Mitig. Adapt. Strat. Global Change 1:218-232.

Shah Z, Shah SH, Peoples MB, Schwenke GD, Herriedge DE, 2003. crop residues and fertilizer $\mathrm{N}$ effects on nitrogen fixation and yields of legumes-cereal rotations and soil organic fertility. Field Crop. Res. 
83:1-11.

Semenov MA, Wolf J, Evans LG, Eckerstern H, Iglesias A, 1996. Comparison of wheat simulation models under climate change. II. Application of climate change scenarios. Climate Res. 7:271-281.

Thornton PK, Hoogenboom G, Jones JW, 1994. Sequence analysis. In: G.Y. Tsuji, G. Uehara and S. Balas (eds.) DSSAT Ver. 3, Vol. 3-2, University of Hawaii Publ., Honolulu, HI, USA.

Tsuji GY, Hoogenboom G, Thornton PK, 1998. Understanding options for agricultural production. Systems Approaches for Sustainable Agricultural Development. Kluwer Academic Publ., Dordrecht, The Netherlands.

Ventrella D, Charfeddine M, Moriondo M, Rinaldi M, Bindi M, 2011. Agronomic adaptation strategies under climate change for winter durum wheat and tomato in Southern Italy: irrigation and nitrogen 3.

Ventrella D, Giglio L, Rinaldi M, Moriondo M, Bindi M, 2008. Vulnerability of some herbaceous crops to climate change in Southern Italy. Ital. J. Agron. 3(Suppl.3):789-790.

Ventrella D, Rinaldi M, Charfeddine M, Ruggieri S, Giglio L, Moriondo M, 2009. Adattamento ai cambiamenti climatici per frumento duro e pomodoro in ambiente Mediterraneo: Irrigazione e concimazione azotata. XXXVIII Convegno Nazionale della Sociètà Italiana di Agronomia, 67-68.

Weiss A, Hays CJ, Won J, 2003. Assessing winter wheat response to climatic change scenarios: a simulation study in the U.S. Great Plains. Climatic Change 58:119-147. 